\title{
Estado democrático de direito: deslocamentos e ambiguidades na argumentação
}

\section{Sóstenes Ericson}

Docente da Universidade Federal de Alagoas (UFAL), Brasil. sericson1@hotmail.com

Resumo: Neste trabalho, considerando dizeres pronunciados por Dilma Rousseff (2016) e Michel Temer (2017), são analisados os deslocamentos e ambiguidades em funcionamento na argumentação acerca do "Estado Democrático de Direito". Tendo em conta as contribuições de Courtine (2006) sobre o discurso político, e fazendo uma aproximação com Corten (1999) no que diz respeito ao político "como cena das forças políticas" (p. 38), considera-se o conceito de condições de produção do discurso apresentado por Pêcheux (2009), para analisar as cenas enunciativas (GUIMARÃES, 2002) e nelas os deslocamentos e ambiguidades. Os enunciados apontam para contradições não somente entre governos, mas também entre projetos distintos, orientados a partir de perspectivas de classes sociais antagônicas, produzindo efeitos de sentido sob o simulacro do Estado Democrático de Direito.

Palavras-chave: Discurso político. Argumentação. Estado. Democracia.

Abstract: In this work, considering the statements made by Dilma Rousseff (2016) and Michel Temer (2017), we analyze the displacements and ambiguities in operation in the argumentation about the "Democratic State of Law". Taking into account the contributions of Courtine (2006) on political discourse, and making an approximation with Corten (1999) regarding the politician "as a scene of political forces" (p. 38), we use the concept of production conditions of discourse presented by Pêcheux (2009), to analyze the enunciative scenes (GUIMARÃES, 2002) and in them the displacements and ambiguities. The statements point to contradictions not only between governments, but also between different projects, oriented from the perspectives of antagonistic social classes, producing sense effects under the simulacrum of the Democratic State of Law.

Keywords: Political discourse. Argumentation. State. Democracy. 


\title{
Introdução
}

O presente artigo se inscreve no campo do discurso político, considerando a conjuntura brasileira de 2016/2017 e mais especificamente dois momentos importantes no cenário nacional, aqui representados em dizeres enunciados por Dilma Rousseff e Michel Temer acerca do Estado Democrático de Direito. A partir da circulação de pronunciamentos de Dilma e de Temer na mídia, busca-se analisar os deslocamentos e ambiguidades em funcionamento na argumentação.

\section{Sobre o discurso político}

Courtine (2006)', no livro "Metamorfoses do discurso político: derivas da fala pública", considera que na tradição linguística francesa, "especificamente desenvolvida na esteira de uma análise do discurso inspirada no marxismo" (COURTINE, 2006, p.62), o interesse residia "em demonstrar a diferenciação linguística de grupos sociais e políticos, de classes sociais, mas também de partidos políticos ou associações". É nessa conjuntura, entremeada com os eventos de maio de 1968, que Courtine (2006) enfatiza o papel considerável que Michel Pêcheux desempenhou na constituição da Análise do Discurso (AD), numa base ancorada "no trabalho teórico sobre a articulação da linguística e da história numa perspectiva marxista” (COURTINE, 2006, p.63).

Ainda na mesma obra, e agora tratando do que considerou "operações e objetos da Análise do Discurso", Courtine ressaltou que a respeito do discurso político é necessário especificar seu sujeito, entendendo que:

\begin{abstract}
O sujeito político, aquele que enuncia um discurso, está realmente assujeitado a um todo de muitas condições de produção e recepção de seu enunciado. Ele é ponto de condensação entre linguagem e ideologia, o lugar onde os sistemas de conhecimento se articulam na competência linguística, diferenciando-se um do outro, mesclando-se um ao outro, combinando com um outro ou afrontando-o em uma determinada conjuntura política (COURTINE, 2006, p.64).
\end{abstract}

Não menos importante é a definição de corpus discursivo apresentada por Courtine, a partir da qual ele aponta que:

\footnotetext{
${ }^{1}$ Conforme o referido autor, o discurso político se tornou o principal objeto da Análise do Discurso na França, constituindo "o signo de uma particularidade da situação teórica e política francesa nos anos 70" (COURTINE, 2006, p.60).
} 
a operação de extração de um corpus de discurso político, primeiramente, consiste em delimitar o campo discursivo de referência (que é um tipo de discurso: discurso político; seja o discurso que nasce a partir de uma fonte particular no interior do campo do discurso político: discurso produzido pelo falante que pertence àquela formação política, seja o discurso que nasce de uma fonte em um momento histórico definido, por exemplo, o discurso produzido pela formação naquela conjuntura etc.), ao impor uma série sucessiva de coerções sobre os materiais que os tornam homogêneos (COURTINE, 2006, p.66).

Ainda de acordo com Courtine (2006, p.68), como "os discursos políticos enfrentam-se uns aos outros, entrando em contradições ideológicas que ao mesmo tempo os unem e os dividem", é preciso considerar, por consequência, que "todo discurso político deve ser pensado como uma unidade dividida, dentro de uma heterogeneidade em relação a si mesmo, que a análise do discurso político pode ser capaz de traçar" (COURTINE, 2006, p.68).

A partir do pressuposto da heterogeneidade do discurso, recorre-se a Corten (1999, p.37)², para quem a política é "a área funcional especializada, na qual, através das instituições políticas, se realizam as atividades políticas. Corresponde a uma imposição que obriga a atividade política a se declarar". 0 político, por sua vez, "é a realidade das forças (e forças políticas) tais como essas se destacam de maneira mais ou menos precisa, à vista de todos" (CORTEN, 1999, p.37). Nesse sentido, Corten (1999, p.38) considera que "o político como cena das forças políticas - cena construída pelo discurso - não corresponde ao discurso político tampouco o discurso compreendido no sentido amplo do termo com sua carga correspondente de poder".

Tendo em conta a representação das forças políticas, Corten (1999, p.38) entende que "o político, como cena de representação, nem sempre existiu, nem é comum a todas as sociedades contemporâneas". Para o referido autor, o político "é uma construção da realidade a partir da qual (no limite) se estabelece a 'discriminação' entre os amigos e os inimigos” (CORTEN, 1999, p.39), sendo a discriminação a essência do político. A representação do político então constitui "a cena das forças políticas construídas pelo discurso" (CORTEN, 1999, p.37), razão pela qual "o discurso político cria a cena que sua

\footnotetext{
2 Por enquanto fica adiada uma análise sobre a metáfora do Príncipe, numa aproximação com Maquiavel.
} 
enunciação produz e, ao mesmo tempo, pressupõe para legitimar-se" (CORTEN, 1999, p.42).

Partindo das contribuições de Marandin (1979), Courtine (2006) apresenta uma questão ampla que aqui será recuperada, numa tentativa analítica de demonstrar na atualidade a sua relevância: "como o discurso político torna real o ponto de vista de um sujeito, como apresenta os objetos do mundo, como ordena esses objetos em uma expressão linguística que um sujeito, por sua vez, pode formular?" (COURTINE, 2006, p.68).

Considerando o investimento teórico para desvelar o sentido do político hoje, seleciona-se uma sequência de enunciados, para pensar os deslocamentos e ambiguidades na argumentação do discurso político e, ao fazê-lo, identificar as fronteiras de sua topografia (nos termos apresentados por Corten, 1999), mobilizando os pressupostos teórico-analíticos da AD inaugurada por Pêcheux para fazer trabalhar as noções, conceitos e categorias nas margens do discurso.

Tem-se em conta que as condições de produção do discurso são "determinações que caracterizam um processo discursivo, inclusive as características múltiplas de uma situação concreta que conduz à produção do sentido linguístico" (PÊCHEUX; FUCHS, 1997, p.183), considerando que o sentido vai além de sua materialidade linguístico-sintática. Esta noção traz um componente amplo (determinações que caracterizam um processo discursivo), como também considera um caráter restrito (características múltiplas de uma situação concreta que conduz à produção do sentido linguístico).

Os sentidos produzidos, em condições de produção dadas, decorrem da imbricação de dois componentes: intradiscurso e interdiscurso. Para Pêcheux (2009, p.154, grifos do autor), o intradiscurso é "um efeito do interdiscurso sobre si mesmo, uma 'interioridade' determinada como tal 'do exterior”. Por sua vez, "o interdiscurso enquanto discurso-transverso atravessa e põe em conexão entre si os elementos discursivos constituídos pelo interdiscurso enquanto pré-construído" (idem, grifos do autor). Tais componentes são submetidos aos efeitos ideológicos dentro das formações discursivas. Ainda de acordo com Pêcheux, uma formação discursiva é "aquilo que, numa formação ideológica dada, determinada pelo estado da luta de classes, 
determina o que pode e deve ser dito (articulado em forma de uma arenga, de um sermão, de um panfleto, de uma exposição, de um programa etc.)" (PÊCHEUX, 2009, p.147, grifos do autor).

Com base nesses pressupostos, a memória discursiva, considerada interdiscursivamente (PAVEAU, 2007), constitui então no intradiscurso a abertura para o atravessamento desse discurso-outro, enquanto presença virtual na materialidade descritível da sequência, marcando, "do interior desta materialidade, a insistência do outro como lei do espaço social e da memória histórica, logo como o próprio princípio do real sócio-histórico" (PÊCHEUX, 2008, p.55), abrindo possibilidade para interpretar.

Para além da explicação de como os discursos são produzidos, as suas condições de produção possibilitam ao analista interpretar o processo de produção dos efeitos de sentido que daí decorrem, enquanto uma condição constitutiva no discurso que articula realidade histórica, materialidade linguística e sujeito, sendo estes os pressupostos que fundamentam a presente análise.

\section{Cenas enunciativas e ambiguidades no discurso político}

Recuperando o conceito de cena enunciativa ${ }^{3}$, considera-se que nesta

'aquele que fala' ou 'aquele para quem se fala' não são pessoas, mas uma configuração do agenciamento enunciativo. São lugares constituídos pelos dizeres e não pessoas donas de seu dizer. Assim, estudá-la é necessariamente considerar o próprio modo de constituição destes lugares pelo funcionamento da língua (GUIMARÃES, 2002, p.23, grifos do autor).

Esta distribuição de lugares se faz pela temporalização própria do acontecimento. Neste sentido, a temporalidade específica do acontecimento, é fundamento da cena enunciativa (idem, ibidem). A noção de temporalidade, então, permite pensar com Corten (1999), os enunciados originários e a circulação no discurso político. Para o referido autor, "as constituições do discurso político se apresentam como repetições de um enunciado que elas constroem como fundador. Esses enunciados definem limites para os outros

\footnotetext{
${ }^{3}$ Trata-se de um espaço particularizado por uma deontologia específica de distribuição dos lugares de enunciação do acontecimento. Assim, assumir a palavra é pôr-se no lugar que enuncia, onde lugares sociais e lugares do dizer expõem-se no espaço de sujeitos divididos por seus direitos ao dizer e aos modos de dizer (GUIMARÃES, 2000). Esse espaço é político.
} 
enunciados" (CORTEN, 1999, p.42). Por seu turno, o campo de circulação discursiva excede o espaço fechado da representação das forças políticas, operando sob duas formas: as fórmulas que conferem sua plausibilidade a essas forças (a exemplo dos enunciados originários) e as versões narrativas que vão permitir aceitabilidade. Como efeito dessas formas, a cena de representação das forças políticas introduz ou apaga distinções (CORTEN, 1999). As duas formas são, no entanto, faces de um mesmo processo, no qual as versões narrativas procuram garantir a atualidade do acontecimento, estando sujeitas a equívocos, a falhas, assim como o próprio da cena da representação.

É o que se identifica em um pronunciamento feito pela então presidenta Dilma Rousseff em 22/03/2016 ${ }^{4}$, conforme agenda oficial, durante um encontro com juristas no Palácio do Planalto, do qual foi extraída a sequência discursiva (SD) a seguir:

SD1 - Quando tudo isso acontece fica nítida a tentativa de ultrapassar o limite estabelecido pelo Estado democrático de direito, a tentativa de cruzar a fronteira, fronteira que é tão cara para nós que a construímos e lutamos por ela; fronteira que separa o Estado democrático de direito do Estado de exceção. Seja esse Estado de exceção ditadura militar, regime policial ou autoritarismo disfarçado.

Chama a atenção o primeiro momento da SD, em que a lista de argumentos apresentados pelo sujeito da enunciação, e feitos em primeira pessoal do singular", é sintetizada pelo eufemismo ("tudo isso") para demonstrar a ameaça ao "Estado democrático de direito". Como efeito da argumentação na personificação do poder do Estado, agora ameaçado por "tudo isso", são identificados elementos de dizer do campo privativo do sujeito da enunciação ("eu jamais imaginei depois do fim da ditadura" e "Eu preferia não viver este momento"), que se ampliam para incorporar seus

4 Disponível em: https://oglobo.globo.com/brasil/leia-integra-do-discurso-da-presidente-dilmarousseff-18934209. Em vídeo, disponível em: https://www.youtube.com/watch?v=S7tO8-ZioBA. Acesso em 11 de agosto de 2017. O texto do referido pronunciamento não foi localizado nos arquivos presidenciais.

5 "Eu denuncio aqui, por conta disso, a estratégia do "quanto pior melhor", que parte das oposições assumiu desde o início do meu segundo mandato, inconformada com os resultados das urnas. Essa estratégia do "quanto pior melhor" ela vem sendo uma ação sistemática, antirepublicana e antidemocrática que se manifesta e se manifestou em pautas-bomba e na busca de motivos falsos e inconsistentes para tirar o mandato a mim outorgado pelo povo brasileiro." (ROUSSEFF, 2016, s/p). 
interlocutores no compromisso com a defesa do Estado (democrático de direito) ameaçado. É importante observar esse movimento entre o "Eu dirijome a vocês" (repetido três vezes ao longo do pronunciamento, vindo logo após os cumprimentos formais iniciais) para o "Juntos, tenho certeza, que iremos defender as instituições das ameaças que estão sofrendo".

O limite identificado no intradiscurso entre o Estado democrático de direito e o Estado de exceção é, portanto, um espaço de intervenção nesta análise. Destaca-se nesse momento que, para reforçar a ameaça no limite que está posto no campo do discurso político, há um interdiscurso produzindo sentido, a partir de uma memória que se faz necessária para produzir o apoio dos interlocutores na defesa do Estado ameaçado. Trata-se do discurso sobre a ditadura civil-militar, que retorna como uma das possibilidades (talvez a mais conhecida) de materialização do Estado de exceção - "Seja esse Estado de exceção ditadura militar, regime policial ou autoritarismo disfarçado".

Este limite estabelece no discurso político dois polos que, na argumentação, vão sendo apresentados como distintos e opostos: democracia/direito e a exceção/ilegalidade, sendo a justiça brasileira o espaço de disputa na fratura entre a Constituição e o golpe. Como o próprio do discurso político são apresentados, nos termos de Corten (1999), por antinomia os "amigos e os inimigos". Os amigos são dados a conhecer, na explícita nomeação dos seus interlocutores na cena enunciativa, como "vocês juristas, advogados, professores de direito, a todos que militam nessa área, a todos que trabalham pela Justiça, além dos cidadãos deste País, por defender a normalidade democrática e a Constituição" e os inimigos são apontados como oposições inconformadas com os resultados das urnas, "aqueles que pedem a minha renúncia", um executor da Justiça que assume "como meta condenar adversários ao invés de fazer Justiça". Na cena da representação do discurso político, amigos e inimigos são os interlocutores do sujeito da enunciação e, quando não há possibilidade de consenso, os argumentos apresentados são materializados de modo a persuadir os amigos a lutarem contra os inimigos.

Todavia, convém ressaltar, com base em Corten (1999), que a credibilidade não provém de uma argumentação lógica; resulta da "curvatura dos traçados" num campo discursivo. São alguns dos argumentos 
apresentados no campo de legitimação do argumento - o campo do Direito: "ameaça a normalidade constitucional e a estabilidade democrática no Brasil"; "nós estamos em um regime presidencialista, e o impeachment só pode se dar por crime de responsabilidade claramente demonstrado". Por esta via, o processo de impeachment é considerado um golpe contra a democracia e, portanto, um golpe contra o Estado democrático de direito.

O entendimento lógico dessa conclusão é assumido pelo sujeito da enunciação, reforçando o efeito da argumentação: "Negar a realidade não me surpreende, por isso, o nome é um só: é golpe." ${ }^{6}$ A resposta esperada, como efeito nos seus interlocutores amigos precisa ser apresentada como um elemento que reforça o argumento, ampliando o alcance do efeito, conforme citado a seguir:

Primeiro, eu queria dizer que eu recebo, com muita satisfação e honra, os manifestos assinados por juristas, por advogados, por professores, por membros do Ministério Público, por defensores públicos, por estudantes, enfim, por todos aqueles que militam nessa ampla área, que é a área do direito, da verdade e da justiça do nosso país. Esse ato demonstra algo muito importante para todos nós e para nossa sociedade: o grande compromisso na defesa do Estado democrático de direito que está disseminado pelo País, em todos os estados da Federação. Me alegra muito compartilhar esse momento com cidadãos e cidadãs que têm plena consciência dos riscos de uma ruptura democrática, da monumental perda das árduas conquistas democráticas e sociais obtidas nos últimos anos (ROUSSEFF, 2016, s/p).

Como que atendendo a esse compromisso ampliado nas suas bases de sustentação e em resposta aos ataques dos inimigos (os que "tentam ocultar justamente esse golpe contra a democracia”), são apresentadas as posições assumidas em face do embate, aqui centralizado no campo político: “E eu posso assegurar a vocês que eu não compactuarei com isso. Por isso, não renuncio em hipótese alguma" e "Por isso, tenho certeza: não vai ter golpe". São apresentadas também as expectativas com relação aos interlocutores amigos: "Nenhum brasileiro, nenhuma brasileira pode aceitar e concordar com isso sob nenhuma hipótese ou justificativa" e "Neste momento eu espero ouvir o som do martelo da Justiça sendo batido por juízes, magistrados e ministros sensatos, serenos e imparciais". Observa-se, então, que a credibilidade dependerá do traçado entre a argumentação (alicerçada no

\footnotetext{
${ }^{6}$ Há uma interessante discussão acerca da negação do golpe, como também têm sido comuns as investidas contra as iniciativas de reflexão teórica sobre esse acontecimento.
} 
interdiscurso do Direito) e o poder de persuasão, em funcionamento no sujeito da enunciação: "não renuncio em hipótese alguma" e "tenho certeza".

Embora a distinção seja parte da cena da representação, marcando a topografia no campo do discurso político entre o que precisa ser introduzido e o que precisa ser apagado, seu limite é tênue e possibilita ao analista mobilizar um gesto de interpretação que aponte seus deslocamentos e ambiguidades. Esse é o caso, por exemplo, do Estado democrático (sem o Direito). É possível haver Estado sem democracia e a ditadura civil-militar é um exemplo disso, como também serve para exemplificar que, mesmo nessa condição, o Direito é convocado para assegurar a sua base legal, resguardadas aqui as devidas distinções entre justiça e direito ${ }^{7}$. Todavia, a democracia (direta ou representativa), enquanto regime político, é em si mesma um limite ao poder do Estado, razão pela qual está sempre funcionando como um horizonte (para regimes não democráticos ou antidemocráticos), como um regime ameaçado (em defesa da democracia), ou como um regime "estabilizado".

Decorrido um momento do golpe que culminou com o afastamento da então presidenta Dilma Rousseff, assumiu posição de destaque no cenário político o vice-presidente Michel Temer, já à época alvo de diversas denúncias de corrupção. Foi nessas condições (estritas) de produção do discurso que Temer enfrentou a possibilidade de investigação (que seria conduzida ainda durante o seu mandato de presidente), sendo emblemática a aprovação em 02/08/17 do relatório do deputado Paulo Abi-Ackel (PSDB-MG), contra a proposta de investigação do presidente por corrupção passiva, feita pela Procuradoria-Geral da República (PGR). Nesse momento, a vitória dos inimigos, representados no pronunciamento de Dilma Rousseff, retomou os dizeres ali materializados e, no deslocamento, produziu ambiguidades a partir dos enunciados apresentados por Michel Temer e postos em circulação na mídia em versões narrativas (Figuras 1, 2 e 3 ).

\footnotetext{
${ }^{7}$ Com base em Monte-Serrat e Tfouni (2012), considera-se também a distinção entre o discurso de talhe estável (do Direito) e o discurso de "múltiplas significações" (discurso jurídico), guardando-se a necessária distinção entre sujeito jurídico, enquanto efeito de linguagem, e sujeito de direito, “aquele que é para a lei” (HAROCHE, 1992).
} 


\section{$\mathrm{El} \square \mathrm{dA}$}

Revista Eletrônica de Estudos Integrados em Discurso e Argumentação, Ilhéus, n. 19, ago.2019.

Figura 1 - VEJA (02/08/2017): "Temer: decisão da câmara é uma vitória do estado democrático".

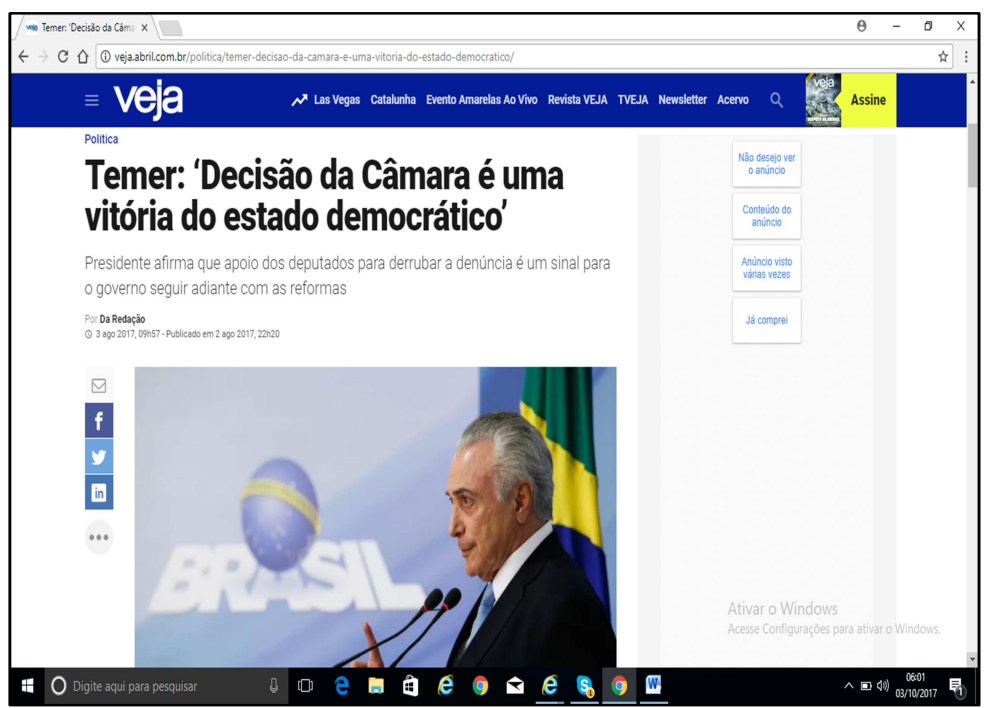

Fonte: http://veja.abril.com.br/politica/temer-decisao-da-camara-e-uma-vitoria-do-estadodemocratico/. Acesso em: 11 de agosto de 2017.

Figura 2 - R7 Notícias (02/08/2017): "Decisão é uma conquista do estado democrático de direito, diz Temer".

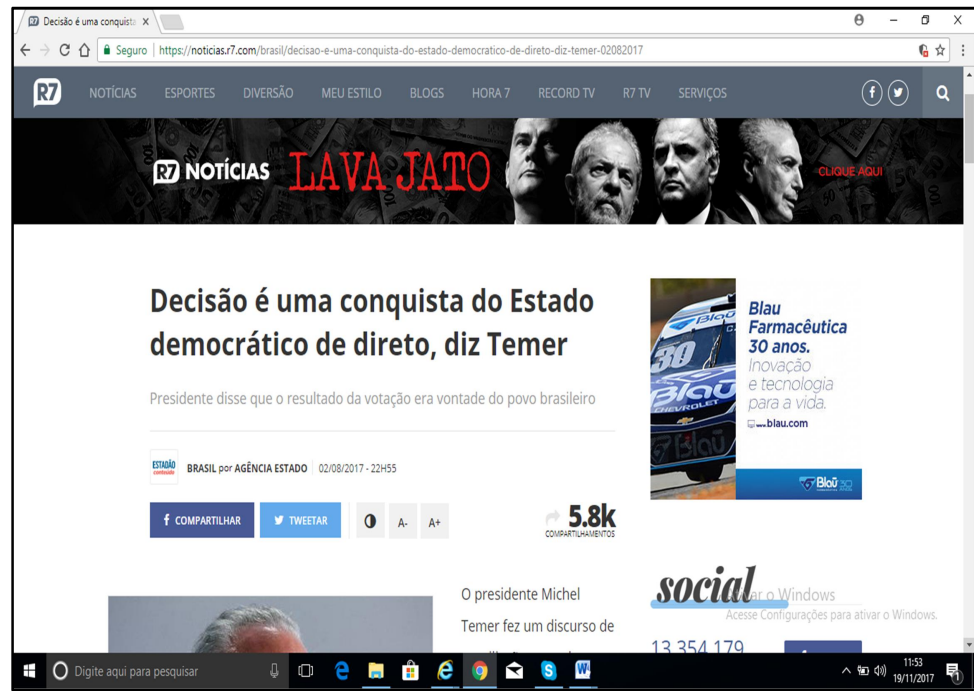

Fonte: https://noticias.r7.com/brasil/decisao-e-uma-conquista-do-estado-democratico-de-direto-diztemer-02082017 
Figura 3 - Revista Isto É (02/08/2017): “Decisão do parlamento é uma conquista do Estado democrático de direito, diz Temer".

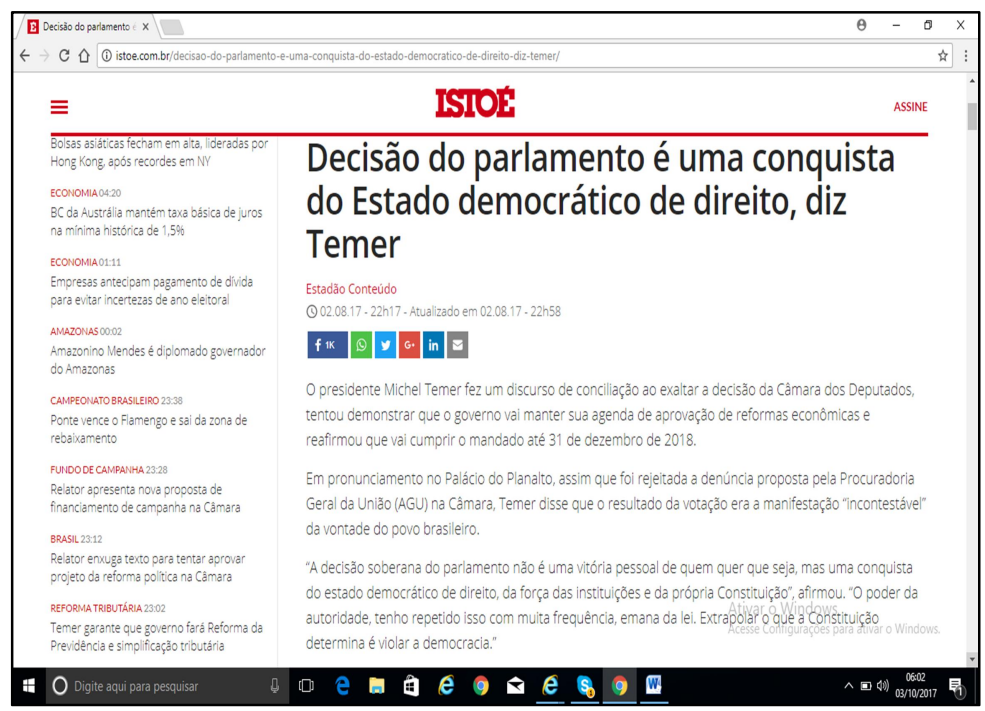

Fonte: http://istoe.com.br/decisao-do-parlamento-e-uma-conquista-do-estado-democratico-dedireito-diz-temer/. Acesso em: 11 de agosto de 2017.

A partir dessas materialidades, põe-se em questão a retomada do enunciado "Estado democrático de direito", ainda que do campo do discurso político, mas agora pondo em funcionamento um deslocamento entre diferentes posições-sujeito numa dada formação discursiva.

SD2 - Temer: "decisão da câmara é uma vitória do estado democrático". (Revista Veja, 02/08/2017, 22h20)

Considerando que, apesar das três publicações terem sido feitas quase que ao mesmo tempo, na primeira (Revista Veja - 22h20) ocorre uma supressão do Direito, sendo as aspas de encerramento do dizer de Temer postas em seguida a "democrático". Enquanto materialidade discursiva, a imagem compõe com o enunciado, e seu enquadramento apresenta as cores da bandeira brasileira, a figura do presidente golpista Michel Temer com dedo em riste, falando com uso de microfones, compondo uma cena que produz sentidos de poder, de autoridade, reforçada pelo destaque ao fundo com a palavra BRASIL, escrita em caixa alta. 
Nas sequências que se seguem, analisa-se o funcionamento de dizeres em seus deslocamentos e ambiguidades.

SD3 - Decisão é uma conquista do Estado democrático de direito, diz Temer. (Agência Estado, 02/08/2017, 22h55).

SD4 - Decisão do parlamento é uma conquista do Estado democrático de direito, diz Temer. (Revista Isto É, 02/08/2017, 22h58).

Os enunciados apresentados nessas SD comparecem no título de capa dos principais jornais e revistas do país no dia seguinte, numa narrativa que contribui para a sua aceitabilidade, na ambiguidade que a designação "Estado democrático de direito" apresenta. Desse modo, os efeitos de sustentação funcionam para inverter o jogo enunciativo, parecendo relativizar os amigos e os inimigos do Estado (democrático de direito). De modo concorrencial, a defesa do referido Estado por parte do (des)governo Temer compõe um simulacro que, pela ambiguidade, tenta produzir um efeito de sustentação de alguns dos argumentos anteriormente apresentados pela então presidenta Dilma Rousseff, a exemplo da ameaça à normalidade constitucional e à estabilidade democrática no Brasil.

A narrativa da Revista Isto É, por exemplo, aponta que "o presidente Michel Temer fez um discurso de conciliação ao exaltar a decisão da Câmara dos Deputados, tentou demonstrar que o governo vai manter sua agenda de aprovação de reformas econômicas e reafirmou que vai cumprir o mandato até 31 de dezembro de 2018". De acordo com Corten, entretanto, na cena de representação do discurso político, o consenso é momentâneo e decorrente da posição, não sendo indício de unanimidade, nem de equivalência das forças em disputa.

$\mathrm{Na}$ cena narrada pela mídia alinhada ao golpe, a representação do discurso de conciliação é funcional, embora sujeita aos deslizes que apontam para a fragilidade do que se revela insustentável. Nesse sentido, "tentou demonstrar" se desloca dos dizeres do político, fragilizando o argumento e a capacidade de persuasão, como também seu efeito de credibilidade. Nessa construção, a necessidade de reafirmação de que "vai cumprir o mandato até 31 de dezembro de 2018" é uma resposta à ameaça existente, a exemplo do que é apontado também (embora por outros mecanismos discursivos) no 
dizer de Dilma Rousseff: "Por isso, não renuncio em hipótese alguma" e "Por isso, tenho certeza: não vai ter golpe".

Todavia, no segundo caso, há algo a mais na argumentação que requisita recuperar alguns elementos do pronunciamento de Dilma Rousseff, no que diz respeito aos indicadores sociais e econômicos. Trata-se da apresentação do que "queremos" e da condição para que o Brasil possa avançar:

Juntos vamos fazer esse Brasil, tão querido, avançar. Queremos muito para o Brasil, por isso estamos aqui. Queremos crescimento, que gera riqueza e empregos. Queremos inclusão social, que consolida e amplia direitos. Queremos tolerância, que viabiliza a convivência na diversidade. Diversidade tão importante para nossa cultura. Tolerância, tolerância e tolerância. Queremos diálogo e queremos paz. Tudo isso somente será possível se preservarmos nossa democracia, fundamento do Brasil melhor, mais justo, que nós todos sonhamos. Sejamos, pois, firmes na defesa da legalidade, na defesa da Constituição e do Estado de direito; na defesa das conquistas que o povo brasileiro conseguiu nos últimos anos do nosso País (ROUSSEFF, 2016, s/p).

Entre o querer, a condição ("somente será possível se preservarmos nossa democracia, fundamento do Brasil melhor, mais justo, que nós todos sonhamos") e a necessidade ("sejamos firmes"), põe-se um efeito de temporalidade que colabora reforçando no argumento também a memória do governo Lula - "conquistas que o povo brasileiro conseguiu nos últimos anos do nosso País". O povo brasileiro então, tomado como parte do "nós" amplia a responsabilidade dos amigos e, ao mesmo tempo, põe em oposição do povo brasileiro os inimigos. No caso do pronunciamento de Michel Temer, não se faz qualquer menção ao povo brasileiro, o que de uma perspectiva discursiva pode ser considerado no limite do silenciamento para o apagamento.

Volta-se então às SD2 a 4 para abordar um aspecto importante do dizer de Temer, em distinção, que, num movimento parafrástico, desliza/desloca sentidos no que circula na mídia:

\footnotetext{
“decisão da câmara é uma vitória do estado democrático” (Revista Veja)

“Decisão é uma conquista do Estado democrático de direito” (Agência Estado)

"Decisão do parlamento é uma conquista do Estado democrático de direito" (Revista Isto É)
}

Com base na superfície discursiva, recuperam-se nas paráfrases os indícios de um funcionamento orientado a partir de duas posições distintas: 1. 
Uma vitória do estado democrático na decisão (da câmara); 2. Uma conquista do Estado democrático de direito na decisão do parlamento. Para além do sentido de "parlamento", apontando também para um regime de governo (parlamentarista), tem-se uma possibilidade do Estado democrático sem o direito (aqui em termos muito específicos), como também uma decisão que não tenha se dado necessariamente na câmara, ou no parlamento.

- Decisão da câmara [do parlamento] é uma vitória [conquista] do estado democrático [de direito].

- Decisão [da câmara/do parlamento] é uma conquista [vitória] do estado democrático de direito

O surgimento da designação "parlamento", a distinção entre vitória e conquista, bem como a supressão da câmara/do parlamento e do direito colaboram com um posicionamento sobre o (des)governo, com implicações no que se pretende sobre o Estado, ou sobre uma determinada forma Estado, que se põe em minúsculo, caso do enunciado trazido pela Revista Veja ("estado democrático").

É preciso considerar, no entanto, que "o Estado moderno não passa de um comitê administrativo dos negócios da classe burguesa em seu conjunto" (MARX; ENGELS, 2001, p.53), razão pela qual a esfera do Direito torna-se fundamental, uma vez que, para a classe dominante, "o seu direito não é senão a vontade da sua classe erigida em lei, uma vontade cujo conteúdo é determinado pelas condições materiais de existência de sua própria classe" (idem, p.69).

Analisando a relação indissociável entre o Estado e o Direito privado, Marx e Engels afirmaram que:

Como o Estado é a forma em que os indivíduos de uma classe dominante fazem valer os seus interesses comuns e se condensa toda a sociedade civil de uma época segue-se que todas as instituições comuns [gemeinsamen] que adquirem uma forma política, são mediadas pelo Estado. Daí a ilusão de que a lei assentaria na vontade e, mais ainda, na vontade dissociada da sua base real, na vontade livre. Do mesmo modo o direito é, por sua vez, reduzido à lei (MARX; ENGELS, 2009, p.112, grifos do autor).

Nesse sentido, Estado e Direito privado tem uma base real comum, o que põe a esfera econômica e a esfera política em condição de distinção e de indissociabilidade. Para Marx e Engels (2009, p.112), "o direito privado 
desenvolve-se, simultaneamente com a propriedade privada, a partir da dissolução da comunidade natural”. Este é, portanto, um princípio que põe em causa as diferentes esferas do direito, quer se esteja dando ênfase ao âmbito constitucional, quer se esteja tratando da esfera criminal, civil ou trabalhista. Suas distinções e mediações não anulam o aspecto decisivo da propriedade privada, ainda que "no direito privado, as relações de propriedade vigentes são ditas [ausgesprochen] como resultado da vontade geral" (MARX; ENGELS, 2009, p.113, grifo dos autores), embora não sejam.

No que toca a esta análise, a eminência de um afastamento provocou a necessidade de um dizer que se deslocasse do campo político para, pelo interdiscurso, reclamar o cumprimento da lei em defesa do Estado. Esse deslocamento faz operar um mecanismo que se amplia da ameaça ao governo para a ameaça ao Estado e joga na cena enunciativa dizeres que, pela ambiguidade, produzem um sentido de relatividade nas forças em disputa, no campo político, em sua heterogeneidade constitutiva.

Analisando a Revolução Francesa, Marx (2008, p.105) afirmou que "a sombra do golpe de Estado tornara-se tão familiar aos parisienses sob a forma de fantasma que, quando finalmente apareceu em carne e osso, não queriam acreditar no que viam". A produção desse efeito de sentido, no entanto, diz respeito ao fato de que

[...] as ameaças revolucionárias da pequena burguesia e de seus representantes democráticos não passam de tentativas de intimidar o adversário. E quando se veem em um beco sem saída, quando se comprometeram o suficiente para tornar necessário levar a cabo suas ameaças, fazem-no de maneira tão ambígua, que evita principalmente os meios de alcançar o objetivo e tenta encontrar pretextos para sucumbir (MARX, 2008, p.52).

Guardadas as devidas condições materiais que distinguem a Revolução Francesa e o que foi analisado neste trabalho, ressalta-se a necessária utilização da ambiguidade no processo de levar a acabo as ameaças da burguesia, para produzir sentidos outros, a exemplo da defesa do Estado, da pátria brasileira, ou como apresentado na matéria da Revista Veja, do BRASIL, o país verde e amarelo, como reclamam para si aqueles que conscientemente ou não se filiam à onda conservadora. Considerando a SD4, observa-se ainda que um país com regime presidencialista, a depender das condições objetivamente postas, pode ter um (des)governo que eleve a estima da 
Câmara dos Deputados, conferindo-lhe, por conveniência, status de parlamento (no sentido de regime parlamentarista), embora esta não tenha deixado de ser uma possibilidade que, vez ou outra, retorna como uma saída para o imbróglio político brasileiro.

\section{Considerações finais}

Este trabalho mobilizou um gesto analítico considerando dois momentos recentes da vida política brasileira, de onde se extraiu a expressão referencial “Estado Democrático de Direito", a partir da qual foram analisados os deslocamentos e ambiguidades com os quais compôs as cenas enunciativas no discurso político e em sua circulação.

Considerando os lugares discursivos e de enunciação, identificou-se que amigos e inimigos são assumidos como posições alinhadas a determinado locutor, de onde se faz apresentar seus interlocutores, em um funcionamento dado no deslocamento de dizeres que, em condições de produção dadas, produzem outros sentidos, como efeito de unidade. Nesta perspectiva, “Estado democrático de direito" representaria um dizer que se constitui a partir do argumento de que o Estado brasileiro estaria ameaçado.

Todavia, considerando que as redes de relações dos discursos não são lineares nem transparentes, ao se questionar que Estado, que democracia, que direito, o argumento de ameaça do Estado desloca-se para a ameaça de determinado governo (Dilma e Temer), ao tempo em que, pela memória do regime de ditadura civil-militar, reforça o argumento em torno da democracia, como um regime baseado no direito à liberdade e ao voto, sendo este último o que tornaria, em condições gerais, legítimo o governo Dilma.

Em se tratando de um governo golpista, entretanto, o funcionamento discursivo do "Estado democrático de direito" não se sustenta no argumento do voto, nem traz à tona a defesa da vontade soberana do povo. Antes põe a centralidade na encenação levada a cabo pela Câmara dos Deputados que, em sua maioria, votou pelo arquivamento da denúncia contra o presidente golpista Michel Temer. Tinha-se, nos dois casos, certo "Estado Democrático de Direito" fazendo valer o rito legal, embora as determinações objetivas não estivessem circunscritas a essa dimensão das forças em disputa. 
Em posições-sujeito distintas, Dilma e Temer se colocaram em defesa do “Estado Democrático de Direito", havendo em comum a necessidade de permanência no cargo político. Todavia, no primeiro caso, cumprido o rito legal, fez-se conforme determinava (de acordo com os interesses que lideravam o golpe) a lei; a maioria dos Deputados votou pelo impeachment da presidenta eleita Dilma Rousseff. No segundo caso, mantido o rito legal, a maioria dos Deputados votou pelo arquivamento da denúncia contra o presidente golpista Michel Temer.

Para além da superfície do dizer, no entanto, os enunciados nas duas cenas enunciativas e na circulação discursiva apontam para contradições não somente entre governos, mas também entre os distintos projetos orientados a partir da perspectiva de classes sociais antagônicas. É por esse entendimento que Dilma e Temer assumem posições-sujeito distintas no campo do discurso político e é a partir das filiações com formações discursivas e formações ideológicas que os sentidos de "Estado Democrático de Direito" deslizam, ora sob o argumento em defesa da Constituição Federal, guardiã dos interesses do povo brasileiro, ora sob o argumento do papel do poder legislativo, em salvaguardar os interesses das classes dominantes ( simbolizadas no verde e no amarelo) e o silenciamento das classes populares. Os desmontes das políticas públicas no (des)governo Temer são exemplos concretos da ofensiva dos inimigos da classe trabalhadora do Brasil, que operam sob o simulacro do Estado Democrático de Direito.

\section{Referências}

CORTEN, André. Discurso e representação do político. In: INDURSKY, Freda; FERREIRA, Maria Cristina L. (Org.). Os múltiplos territórios da Análise do Discurso. Porto Alegre: Sagra Luzzatto, 1999. Coleção Ensaios, vol. 12. p.37-52.

COURTINE, Jean-Jacques. Metamorfoses do discurso político: derivas da vida pública. Organização: Carlos Piovezani Filho e Nilton Milanez. Revisão: Maria do Rosário Gregolin. São Carlos: Claraluz, 2006.

GUIMARÃES, Eduardo. O Político e os Espaços de Enunciação, 2000. (mimeo). . Semântica do Acontecimento. Campinas: Pontes, 2002. 
HAROCHE, Claudine. Fazer dizer, querer dizer. São Paulo: Ed. Hucitec, 1992.

MARX, Karl. 018 Brumário de Luis Bonaparte. 2. ed. São Paulo: Martin Claret, 2008.

; ENGELS, Friedrich. A ideologia alemã. São Paulo: Expressão Popular, 2009.

. Manifesto Comunista. 3. ed. Rio de Janeiro: Garamond, 2001.

MONTE-SERRAT; Dionéia Motta; TFOUNI, Leda Verdiani. A suposta igualdade perante a lei: as dissonâncias do discurso na audiência do poder judiciário. Letra Magna Revista de Divulgação Científica em Língua Portuguesa, Linguística e Literatura, v. 8, n. 15, 2012.

PAVEAU, Marie-Anne. Reencontrar a memória: percurso epistemológico e histórico. Tradução: Carlos Piovezani Filho. In: INDURSKY, Freda; FERREIRA, Maria Cristina Leandro. (Org.). Análise do discurso no Brasil: mapeando conceitos, confrontando limites. São Carlos: Clara Luz, 2007. p.239-250.

PÊCHEUX, Michel. O Discurso: Estrutura ou Acontecimento. Tradução: Eni Puccinelli Orlandi. 5. ed. Campinas: Pontes, 2008.

- Semântica e Discurso: uma crítica à afirmação do óbvio. Tradução: Eni Puccinelli Orlandi et al. 4. ed. Campinas: Pontes, 2009.

PÊCHEUX, Michel; FUCHS, Catharine. A propósito da análise automática do discurso: atualizações e perspectivas (1975). In: GADET, F.; HAK, T. (Org.). Por uma análise automática do discurso: uma introdução à obra de Michel Pêcheux. 3. ed. Campinas: Ed.Unicamp, 1997.

SILVA, Soeli Maria Schreiber da. A argumentação e inclusão na prática política de linguagem: a questão do ensino. Disponível em: http://www.ufscar.br/ uehposol/art_passo.htm. Acesso em: 13 ago.2017.

\section{Forma de citação sugerida}

ERICSON, Sóstenes. Estado democrático de direito: deslocamentos e ambiguidades na argumentação. EID\&A - Revista Eletrônica de Estudos Integrados em Discurso e Argumentação, Ilhéus, n. 19, p. 103-120, ago.2019. DOI dx.doi.org/10.17648/eidea-192269. 